\title{
Teaching English through Poetry: A Powerful Medium for Learning Second Language
}

\author{
Dr. Reena Mittal \\ MA (Eng.), Ph.D., MBA Reader and Head, Department of English, DAK Degree College, Moradabad
}

\begin{abstract}
Poetry was not considered apt and appropriate for second language learning especially when we talk about Grammar, communication skills etc. But poetry serves not only a model of literature but a model for teaching skills of language as reading and writing. Poetry can be an effective way of language teaching. The student can easily relate structures and themes with the help of poetry. We must always remember that our old Fables, Tales and Japanese 'Tanka', were sung and we still remember them by heart. This article focuses on use of poetry in ELL and ways of using poetry in ELL classrooms.

Key Words: Narrative, Pronunciation, Motivation, Confidence, Rhythm.
\end{abstract}

Poetry always awakens our senses, promotes literary. It helps students to draw a sketch or image of everything in their mind which they can feel, explain and talk about. Poetry is musical and rhythmic, so it catches everyone's attention. Poetry is universal and global so it connects people. It is a vehicle for expression on a wider horizon. Poetry requires concentration and attention both which usually students did not adhere on. Poetry is so versatile that it can make great changes in ELT. Poetry is of many types and forms. Similarly language of poetry can be simple or ornamental. Poetry opens with an interesting historical reference of Epics, Folk Tales and many other references; not only in India but in many other Non-English speaking countries.

A poetry is a piece of writing in which words are arranged beautifully and rhythmically. We have recently celebrated World Poetry Day on $21^{\text {st }}$ March and suddenly this idea struck into my mind to write something on this topic. Studying and writing poetry can give expression and communication to the students and teachers both. We need poetry to promote language teaching emotionally and holistically. Poetry helps to use Figure of Speech, Adjectives, Phrases and symbolic words spontaneously to show feelings. When we read, listen or write something aloud and rhythmically we easily learn it.

There are a number of ways to use poetry for ELL Classroom. Poetry offers many opportunities for language teaching and practice. It gives a wide chance of learning vocabulary and structure. To start poetry in ELL in classroom is not an easy way. The very first thing which a teacher has to do is to prepare students for poetry. First, a teacher must know how much student know about poetry and its forms, construction, rhyme and rhythm. Poetry ranges from simple to complex. In present day, even absurd poetry is also in great demand. Depending on the level of students, we can start use of poetry in classroom in various ways such as:

- Discussion about the difference between Poems and Prose.

- Give a short story and ask to convert some lines in a poetic composition.

- Read poems loudly and tales and prose in poetic manner so that students can follow.Reading aloud always works well as far as pronunciation and fluency is concerned. In order to increase fluency, pronunciation and confidence, classroom practices and exercises play an important role.

- Vocabulary is also very important because there are many words which can only be used in poetic composition. So, vocabulary games and quiz also play an important role.

- Poems have some unusual sentences and structures which students normally will not find in prose. Their sentences and structure help a lot in ELL.

The aim of teaching English through poetry is to provide inspiration of learning language with emerging techniques and practical wisdom and ideas. It does not mean that English teaching means learning poetry but to learn $\mathrm{L}_{2}$ (English) with the help of poetry enthusiastically. Learning through poetry needs extra attention and motivation as students have to devote more time and energy.

Poetry for teaching is helpful because it works well as a catalyst over mind. It is often called 'balm for soothing mind', similarly it's a versatility make learning motivating, memorable and involving the whole classroom. If we go in the history of poems, we find Epics, Tales and Folk lore which are sung by so called illiterate people but they learn it by heart and reproduce it many a times all the same. Similarly 'Tanka' in Japan and 'Shi' in China also promote language teaching with great success. They make historical, cultural and mythological references learn by heart easily and enrich our knowledge of particular language. There are several advantages which students can get through poetry such as:

- A student can use and fit words in poetic composition. 
- Correct use of vocabulary and grammatically correct language can be learned.

- Students can I earn use of Thesaurus, Phrases, Structure, verb and tenses.

- Nurture student's imagination and creativity as well as build their confidence level.

There are the basic uses poetry can bring into EET (Effective English Teaching). It brings emotions, rhyme and congenial expression in classroom.Poetry works for enrichment of language because it:

- Enrich vocabulary

- Sound, Rhythm and stress

- Pronunciation and fluency.

Each coin has two sides; so is everything has some pros and cons. Teaching English through Poetry is time consuming and sometimes wrong construction of poem can make the results worst. A right click always enhance the beauty, similarly bad click make the memory worse.Some activities which will help in learning language through poetry:

- Worksheets of vocabulary, quiz.

- Sentences connected with each other.

- Rhyming words.

- Events whose pictures can be shown to the students.

- $\quad$ Language lab with recording facility and background music facility.

- Some interesting themes based on curriculum, tales and contemporary issues which can cater needs of natives.

- Healthy discussion and debate in class.

- Encouragement and motivation.

There are some assignments and projects that can be made a part of curriculum as:

- Creative writing to add one or two stanzas on most famous poems of syllabus.

- Create a poem with the help of given a group of 50 to 100 words.

- To write applications, letters, reports of events in poetic form.

- Reconstruction of Nursery Rhymes and kids poems is also a good mind blogger.

I personally teach under graduates whose mother tongue is Non English and most of them are from semi- rural background. When University erase Poetry for III Year students, the classroom teaching became dull and monotonous as poetic composition make understanding easier free flowing. When students are asked to imagine and explain, they easily use words, structures and constructions flawlessly. And finding their creativity apt and appropriate, they are boost up. Poetry plays vital role in teaching use of Phrases, structures and construction also.

Poetry develops an understanding of texts and their use in language classrooms. Use of grammar is not easy for Non English background students but they too can exercise it will in poetry. We must not forget our oldest technique 'Narrative' in which tales were sung by people who are not literate even, but their compositions were par excellence. Even Homer's Iliad and Odyssey were also written in this form and they are unparalleled even now. Similarly 'Shi' in China and 'Tanka' in Japan are still popular as they are unrhymed poetic compositions which impart knowledge poetically to all.

Poetry and related activities can play an important role in EET and learning. I have read that many of popular Pop Albums (popular music of today) are the outcome of practice of vocabulary and rhyming words as walking/talking, humming/coming, chance/dance and many more. So, poems and related exercises in classrooms can enhance EET. We as teachers must focus on words, their correct use and construction. Students will understand meaningful and relevant use of language as poetry awakens our senses and help to build oral language skill. It offers wonderful opportunities for expansion of vocabulary and to work with rhyme and rhythm it is so versatile that it opens innumerable openings for teachers and students both. April can always be celebrated as the Month of Poetry.

The main aim of this study is to show that poetry is not a part of literature only. But to understand or adopt a language you have to be necessarily good in poetic formation. Even the plain prose has a poetry which can be understood when you are versatile in both. This paper has attempted to indicate how poetry and related activities might enhance ELL. As a teacher, we have to focus on vocabulary, our target language and use of grammatically correct sentences. A great depth of poetry can be found in songs, folk tale etc. which teach us how important poetry learning and teaching is. It has deep meaning which we have to understand for better understanding of language. 


\section{References}

[1]. Literature in the Language Classroom, Collie \& Slater, 1987.

[2]. Using poems to develop productive skills, Christina Smart, British Council, Hungry 2002

[3]. www. onestopenglish.com.

[4]. www. Channel 14. com/learning.

[5]. www. british council.org/team English - poems. 